КОБЕЛЬКОВ Артем Николаевич - аспирант сектора теории политики Института мировой экономики и международных отношений им. Е.М. Примакова Российской академии наук (ИМЭМО РАН) (117997, Россия, г. Москва, ул. Профсоюзная, 23; temakob@yandex.ru)

\title{
ЭКОНОМИЧЕСКИЕ АСПЕКТЫ ГЕРМАНО-ТУРЕЦКИХ ОТНОШЕНИЙ
}

\begin{abstract}
Аннотация. Экономические связи служат фундаментом любых межгосударственных отношений. Их анализ должен учитывать не только количественные и отраслевые показатели, но и институциональные условия настоящего и перспективного развития торговых и инвестиционных отношений. Экономическое взаимодействие Германии и Турции имеет ключевое значение не только для большого числа предпринимателей в обеих странах, но и для интеграционных процессов на Европейском континенте в целом. Данная статья посвящена изучению ключевых аспектов экономических отношений этих стран с учетом актуального политического контекста и их места в современной системе международных отношений. Структура и состояние двусторонней торговли демонстрирует и определяет основные стратегические стремления Германии и Турции в Европе и в мире.
\end{abstract}

Ключевые слова: Германия, Турция, торговля, инвестиции, европейская интеграция

Э кономическое взаимодействие Германии и Турции развивается по двум направлениям: это наращивание двустороннего торгового и инвестиционного оборота и немецкое содействие в рамках общих усилий ЕС по трансформации Турции в соответствии с копенгагенскими критериями.

По состоянию на 2017 г. Германия занимает 5-6-е место в мире по объемам ВВП по паритету покупательной способности (данные МВФ и ВБ отличаются) и 3-е место по экспорту, уступая только США и Китаю. В этих условиях и «при современном уровне и масштабах производства рынок ФРГ узок для национальных производителей, хотя население страны составляет 82 млн человек и отличается высокой покупательной способностью» [Кузнецов 2004: 43]. Следовательно, Германия является ориентированной на экспорт страной, причем основной объем экспорта приходится на европейские страны (свою роль в этом играет и «эффект соседства»). Такое «замыкание значительной части германской внешней торговли на европейские страны свидетельствует о проявлении регионализации» [Кузнецов 2004: 38], что создает экономический фундамент для немецких усилий по консолидации Европы. Что касается Турции, то за последние годы она пережила в экономическом плане глубокую системную трансформацию.

Экономическое развитие страны шло достаточно быстрыми темпами. ВВП на душу населения вырос с 3500 долл. на душу населения в 2002 г. до 10504 долл. на душу населения в 2012 г. Инфляция за тот же период сократилась с 30 до 6\%. В 2002 г. Турция была должна МВФ 23,5 млрд долл., что делало ее крупнейшим должником этой организации. В мае 2013 г. долги перед МВФ были полностью погашены. В период с 2002 по 2012 г. общий объем экспорта вырос с 36 до 152 млрд долл. В результате Турция является 17-й экономикой мира и 6-й экономикой Европы ${ }^{1}$. Как и в политической сфере, основы успешной трансформации были заложены в более ранний период, однако правительство ПСР умело воспользовалось наработками предшественников. Тем не менее у турецкой экономики сохраняется большое число структурных проблем. Прежде всего, это сохранение зависимости от притока иностранного капитала, дефицит внешней

\footnotetext{
1 The Silent Revolution. Turkey's Democratic Change and Transformation Inventory (2002-2012). Republic of Turkey. Prime Ministry. Undersecretariat of Public Order and Security. 2013. P. 125-126.
} 
торговли, бюрократические барьеры, монополизм, высокая инфляция, высокий порог входа в бизнес и непрозрачная налоговая система. Ведущий отечественный специалист по турецкой экономике Н.Ю. Ульченко считает, что «Говорить о смене модели роста при ПСР нельзя» [Ульченко 2014: 110]. По ее мнению, причиной проблем в экономике Турции является популистская экономическая политика, которая недостаточно ориентирована на экспорт, а главное препятствие, которое необходимо преодолеть, - «самофинансирование инвестиций» [Ульченко 2014: 112], т.к. в условиях оживления экономик развитых стран капитал будет уходить на рынки США и Европы. Действительно, «новая нормальность» затронула и экономику Турции. В 2014-2015 гг. темпы роста турецкой экономики составляют около $2 \%$ при сохранении значительной безработицы и высокой инфляции.

Несмотря на трудности последних лет, можно констатировать, что экономики обеих стран в начале XXI в. сделали существенный шаг вперед. В контексте этих успехов стабильно развивается двустороннее торговое и инвестиционное сотрудничество. На сайте МИД ФРГ приводятся краткие данные о торгово-экономических отношениях Берлина и Анкары. Согласно приведенным данным, общий объем накопленных немецких инвестиций составляет 12,5 млрд евро. Число немецких компаний, работающих в Турции, и число турецких компаний с немецким капиталом достигло 6000 . Они заняты как в сфере промышленности, так и в сфере транспорта и услуг. В Германии работают более 75000 предпринимателей турецкого происхождения и более 370000 сотрудников. Общий оборот этих предприятий достигает 35 млрд евро. Германия занимает 1-е место по числу туристов, прибывших в Турцию (в 2013 г. - до 5 млн чел.). В 1985 г. в Турции было открыто Бюро немецкой промышленности и торговли. В 2004 г. в Кельне была открыта турецко-германская Торгово-промышленная палата, главный офис которой с 2012 г. находится в Берлине. С 1962 г. между странами действует соглашение о защите инвестиций. 19 сентября 2011 г. было подписано новое соглашение об избежании двойного налогообложения (предыдущее действовало в период 1985-2011 гг.). В ноябре 2012 г. министр экономики ФРГ Ф. Реслер и его турецкий коллега Т. Йилдыз выступили с совместной декларацией, призывающей укреплять двустороннее сотрудничество в энергетической сфере. Для диалога по вопросам энергетики был создан германо-турецкий энергетический форум, первое заседание которого состоялось в апреле 2013 г. в Анкаре, а следующее - весной 2015 г. Также весной 2015 г. состоялось первое заседание новообразованной Совместной торговой и экономической комиссии (Joint Economic and Trade Commission) ${ }^{1}$.

В торговой сфере между Берлином и Анкарой наблюдается определенный дисбаланс, т.к., по данным немецкой статистической службы Destatis, Турция для Германии находится на 16-м месте среди всех партнеров по экспорту и на $18-м$ - по импорту. Общий товарооборот между странами составил в 2014 г. 32,6 млрд долл., а в 2015 г. вырос до 36,8 млрд евро².

Как уже упоминалось, помимо развития собственно торговых связей, большую роль играет содействие экономической модернизации Турции, которое осуществляется в рамках переговоров о ее вступлении в ЕС наряду с содействием эволюции политической системы страны. В Брюсселе рассматривают Турцию как часть общеевропейского пространства. В официальных докумен-

1 Türkei. Beziehungen zu Deutschland. Auswärtiges Amt. Infoservice. Web-Archiv. Interviews, Namensbeiträge. September 2015. URL: http://www.auswaertiges-amt.de/DE/Aussenpolitik/Laender/ Laenderinfos/Tuerkei/Bilateral node.html (проверено 17.04.2018).

2 German, Turkish trade volume rises in 2015. - Anadolu Agency. 03.03.2016. URL: http://aa.com.tr/en/ economy/german-turkish-trade-volume-rises-in-2015/530919 (accessed 17.04.2018). 
тах Еврокомиссии регулярно подчеркивается, что ее «стремительное экономическое развитие вносит большой вклад в благополучие всего европейского континента» 1.17 декабря 2013 г. Совет по общим вопросам ЕС решил усилить мониторинг экономического развития стран - кандидатов на вступление в ЕС в связи с увеличением роли экономического управления в процессе расширения EC, а уже в мае 2014 г. Совет по экономическим и финансовым вопросам принял специальную программу сопровождения для Турции. По мнению европейских чиновников, Анкаре необходимо уменьшить макроэкономические дисбалансы и реализовать долгосрочную стратегию роста, т.к. в настоящее время внутри турецкого правительства слабеет консенсус по вопросам экономической политики ${ }^{2}$ В ряду других проблем стоит отметить высокий дефицит внешней торговли, медленный рост занятости и непрозрачность финансовой системы, что определяет сохранение макроэкономических дисбалансов 3 . Практически в каждом отчете Еврокомиссии указывается, что Анкаре «необходимо улучшение координации между бюджетным и среднесрочным экономическим планированием» ${ }^{4}$. Отдельно подчеркивается необходимость либерализации цен, влияние на которые по-прежнему сохраняет государство. К примеру, цены на еду и алкоголь зависят от государственных постановлений более чем на 25\%5. В 2013 г. Турция получила 903 млн евро в рамках Instrument for Pre-accession Assistance $(I P A)^{6}$, которые должны быть расходованы и на структурные реформы экономики, что, согласно мнению разработчиков данной программы, должно приблизить уровень жизни в Турции к среднеевропейскому, т.к. по состоянию на 2012 г. подушевой ВВП составлял $56 \%$ уровня EC 7 . Наряду с финансовым содействием со стороны ЕС Германия также осуществляет финансовое содействие модернизации турецкой экономики. Оказание финансовой помощи Турции со стороны ФРГ происходит в соответствии с Соглашением о финансовом сотрудничестве от 15 марта 2002 г. В соответствии с этим соглашением Германия при посредничестве немецкого Банка реконструкции (Kreditanstalt far Wiederaufbau - KfW, действует от имени федерального министерства экономического развития и сотрудничества Германии) осуществляет кредитование различных программ по строительству инфраструктуры турецких городов [Губанов 2008: 84].

Важнейшим направлением двустороннего сотрудничества остается инвестиционное. Европейский союз остается крупнейшим инвестиционным партнером Турции, о чем свидетельствует тот факт, что в 2012 г. на его долю пришлось $71,3 \%$ всех иностранных инвестиций, поступивших в страну ${ }^{8}$.

Таким образом, торговое и экономическое сотрудничество ФРГ и Турции носит многоплановый характер и является важнейшим компонентом двусторонних отношений. Значимость экономического взаимодействия возрастает в контексте общей «экономизации» мировой политики, когда политические элиты и государства в значительной степени используют «экономические сред-

1 Turkey Progress Report. 2014. URL: https://ec.europa.eu/neighbourhood-enlargement/sites/near/files/ pdf/key_documents/2014/20141008-turkey-progress-report_en.pdf (accessed 18.04.2018). P. 3.

2 Ibid. P. 20.

3 Ibid. P. 23.

4 Turkey Progress Report. 2012. URL: https://ec.europa.eu/neighbourhood-enlargement/sites/near/files/ pdf/key_documents/2012/package/tr_rapport_2012_en.pdf (accessed 18.04.2018). P. 37.

5 Ibid. P. 40.

6 Turkey Progress Report. 2013. URL: https://ec.europa.eu/neighbourhood-enlargement/sites/near/files/ pdf/key_documents/2013/package/tr_rapport_2013_en.pdf (accessed 18.04.2018). P. 5.

7 Ibid. P. 19.

8 Ibid. P. 24. 
ства как фактор борьбы за влияние в мире, регионе или стране» [Дробот 2006: 271]. Следовательно, экономика, торговля и инвестиции становятся ключевым фактором укрепления влияния среди других государств. Стоит отметить, что германо-турецкое экономическое взаимодействие происходит не только в рамках двусторонних отношений, но и в контексте развития глобального актора - Европейского союза, причем происходит это в условиях укрепления в мире либерального торгового режима. Главная задача внешнеэкономической политики ФРГ состоит в консолидации Европы вокруг себя и увеличение своего и общеевропейского экономического потенциала путем «добавления» к нему Турции в качестве рынка сбыта, источника рабочей силы, инвестиционной и промышленной площадки. В свою очередь, Анкара стремится не только извлечь экономические выгоды из сотрудничества с Объединенной Европой, но и стать полноправным членом «ядра» мировой экономической системы. Однако мы разделяем мнение российского исследователя Г. Дробот, что отсталость нельзя преодолеть чисто экономическими методами. Эта проблема может быть решена «только внеэкономическими методами в неопределенной перспективе» [Дробот 2006: 274].

\title{
Список литературы
}

Губанов Н.С. 2008. Туреико-германские торгово-экономические отношения на рубеже 20-21 вв.: проблемы и основные тенденции: дис. ... К.э.Н. М. 198 с.

Дробот Г.А. 2006. Особенности взаимосвязи политики и экономики в глобализирующихся международных отношениях (политологический анализ): дис. ... д.полит.н. М. 305 с.

Кузнецов А.В. 2004. Мирохозяйственные связи германских компаний. М.: ИМЭМО РАН. 124 с.

Ульченко Н.Ю. 2014. Экономическая модернизация Турции: общее и особенное. - Мировая экономика и международные отношения. № 10. С. 105-114.

\section{ECONOMIC ASPECTS OF GERMAN-TURKISH RELATIONS}

\begin{abstract}
Economic ties form the basis of any interstate relations. Their analysis should take into account not only quantitative and sectoral indicators, but also institutional conditions for the present and future development of trade and investment relations. The economic interaction between Germany and Turkey is of key importance not only for a large number of entrepreneurs in each country, but also for integration processes on the European continent as a whole. This article is devoted to the study of key aspects of economic relations of these countries taking into account the actual political context and their place in the modern system of international relations. The structure and state of bilateral trade demonstrates and defines the main strategic aspirations of Germany and Turkey in Europe and in the world.

Keywords: Germany, Turkey, trade, investment, European integration
\end{abstract}

